\title{
ANALISIS CAPITAL ASSET PRICING MODEL (CAPM) DALAM MEMPREDIKSI TINGKAT RETURN SAHAM KOMPAS 100 YANG TERDAFTAR DI BURSA EFEK INDONESIA (BEI) PERIODE 2013-2017
}

\author{
Euis Bandawaty \\ Fakultas Ekonomi dan Bisnis Jurusan Manajemen \\ Universitas Islam As-Syafi'iyah, Jakarta \\ euisbandawaty@yahoo.co.id
}

\begin{abstract}
This study is to determine the accuracy of the CAPM model in predicting 100 compass stock returns listed on the Indonesia Stock Exchange for the period 2013-2017. The variables of this study are 100 stock compass returns, Beta, Risk Free, and Market return. The accuracy of the CAPM model is measured by standard deviation and test. The population of this research is all the monthly stock returns of the compass 100 stock index have gone public on the Indonesia Stock Exchange. While the sample used is a monthly stock return of 58 compass 100 companies during 2013 - 2017. The results of this study indicate that the CAPM model is accurate in predicting 100 stock compass returns.
\end{abstract}

\section{Keywords: Beta, Stock Return, CAPM}

\begin{abstract}
Abstrak : Penelitian ini bertujuan untuk mengetahui keakuratan model CAPM dalam memprediksi 100 return saham kompas yang terdaftar di Bursa Efek Indonesia untuk periode 2013-2017. Variabel dalam penelitian ini adalah tingkat pengembalian saham pada indeks kompas 100, Beta, Bebas Risiko, dan tingkat pengembalian pasar (indek kompas 100) . Keakuratan model CAPM diukur dengan standar deviasi dan uji t. Populasi penelitian ini adalah semua pengembalian saham bulanan dari indeks saham 100 kompas telah go public di Bursa Efek Indonesia. Sedangkan sampel yang digunakan adalah pengembalian saham bulanan 58 kompas 100 perusahaan selama 2013 - 2017. Hasil penelitian ini menunjukkan bahwa model CAPM akurat dalam memprediksi 100 pengembalian kompas saham.
\end{abstract}

\section{Kata Kunci : Beta, Pengembalian Saham, CAPM}




\section{PENDAHULUAN}

Investasi pada bursa saham diyakini memberikan tingkat pengembalian cukup tinggi. Selain menjadi wadah yang mempertemukan pihak-pihak yang membutuhkan dana (emiten) dan pihak-pihak yang kelebihan dana (investor), kegiatan investasi di pasar modal juga dapat memberikan tambahan pendapatan berupa capital gain dan dividen bagi investor. Di sisi lain, pasar modal juga merupakan salah satu indikator ekonomi utama yang dapat digunakan oleh lembaga baik nasional maupun internasional. Dalam membuat keputusan investasi, ada dua faktor yang harus dipertimbangkan, yaitu pengembalian yang diharapkan (expected return) dan risiko yang harus ditanggung (risk). Risiko investasi merupakan konsekuensi yang harus ditanggung oleh investor karena pengembalian di masa yang akan datang dari investasi dalam kondisi ketidakpastian (uncertainty). Investor akan berpikir untuk memaksimalkan return yang diharapkan (expected return) dari setiap rupiah yang mereka investasikan dalam surat berharga. Agar return yang mereka dapatkan adalah return yang maksimal, maka penting bagi investor untuk memperhatikan dan mengestimasikan semua faktor penting yang dapat mempengaruhi return dari investasinya dimasa yang akan datang (Homsud, Nopbhanon, et al, 2009).

Model CAPM dapat digunakan sebagai alat untuk memahami suatu permasalahan yang kompleks dalam gambaran yang lebih sederhana. Untuk memprediksi pendapatan saham yang diharapkan, dapat menggunakan model yang seringkali digunakan para investor, yaitu Capital Assets Pricing Model (CAPM). Bentuk standar dari CAPM diperkenalkan secara terpisah olah Sharpe (1964), Lintner (1965) dan Mossin (1969) merupakan model untuk menentukan harga suatu assets pada kondisi equilibrium. Dimana dalam keadaan equilibrium tingkat keuntungan yang disyaratkan oleh pemodal untuk suatu saham akan dipengaruhi oleh risiko saham tersebut (Tandelilin, 2010: 187). Dalam hal ini risiko yang diperhitungkan adalah risiko sistematis yang diwakili oleh beta, karena risiko yang tidak sistematik bisa dihilangkan dengan cara diversifikasi. Ross (1976) mengembangkan model CAPM dengan memasukkan variabel lain terutama variable makro seperti tingkat suku bunga, inflasi serta aktivitas bisnis memiliki dampak yang signifikan terhadap tingkat perubahan return saham. CAPM merupakan sebuah model yang menggambarkan hubungan antara risiko dan return yang diharapkan. Model ini digunakan dalam penilaian harga sekuritas. CAPM memberikan prediksi yang tepat antara hubungan risiko sebuah aset dan tingkat harapan pengembalian (expected return). Risiko saham dalam CAPM diukur dengan beta $(\beta)$. Pada CAPM, semakin besar koefisien beta, maka akan semakin besar pula return suatu saham dan juga semakin berisiko. Dalam CAPM, tingkat pengembalian yang diharapkan ditentukan oleh tingkat pengembalian pasar, tingkat pengembalian bebas risiko dan risiko sistematis/beta.

Penelitian ini menggunakan indeks saham kompas 100 dimana mengambil sampel 58 perusahaan dari 100 saham perusahaan yang tercatat yang dipilih berdasarkan pertimbangan likuiditas dan kapitalisasi pasar. Dengan membandingkan antara actual return dengan expected return dari suatu perusahaan tang terdaftar di indeks kompas 100 untuk mengetahui dan memprediksi metode capm terhadap return saham kompas 100 pada periode 2013-2017. 


\section{TINJAUAN LITERATUR}

\section{Pasar Modal}

Pasar modal berperan dalam menunjang pelaksanaan pembangunan nasional dalam rangka mengingkatkan pemerataan, pertumbuhan, dan stabilitas ekonomi nasional ke erah peningkatan kesejahteraan rakyat (Sudrajat, 2015:13).

\section{Investasi}

Menurut Jogiyanto (2012), investasi adalah penundaan konsumsi sekarang untuk dimasukkan ke aktiva produktif selama periode waktu yang tertentu. Dengan adanya aktiva yang produktif, penundaan konsumsi sekarang untuk diinvestasikan ke aktiva yang produktif tersebut akan meningkatkan utiliti total. Definisi menurut Kamus Besar Bahasa Indonesia, investasi diartikan sebagai penanaman uang di suatu perusahaan atau proyek untuk tujuan memperoleh keuntungan.

\section{Saham}

Saham merupakan tanda bukti kepemilikan seseorang atau badan terhadap suatu perusahaan. Saham memberikan tingkat pengembalian (Return) berupa deviden, yang biasa dibayarkan setahun sekali dan capital gain (kenaikan harga saham dipasar).

\section{Harga Saham}

Perubahan harga saham menjadi perhatian penting bagi investor dalam melakukan investasi pada pasar modal. Harga saham yang cukup tinggi akan memberikan keuntungan, yaitu capital gain dan citra lebih baik bagi perusahaan sehingga memudahkan bagi manajemen untuk mendapatkan dana dari luar perusahaan. Menurut Jogiyanto (2010:103) menyatakan bahwa perkembangan harga saham merupakan perubahan harga saham yang terjadi di pasar bursa yang ditentukan oleh penawaran dan permintaan saham yang bersangkutan di pasar modal.

\section{Return Saham}

Return adalah laba atas suatu investasi yang biasanya dinyatakan sebagai tarif persentasi tahunan. Return saham merupakan tingkat keuntungan yang akan diperoleh investor yang menanamkan dananya di pasar modal. Return saham ini dapat dijadikan sebagai indikator dari kegiatan perdagangan di pasar modal. Menurut Jogiyanto (2015:263) return merupakan hasil yang diperoleh dari investasi return dapat berupa return realisasi yang sudah terjadi atau return ekspektasi yang belum terjadi tetapi yang diharapkan akan terjadi di masa mendatang.

\section{Risiko}

Risiko dan tingkat pengembalian (Return) memiliki hubungan yang positif. Semakin tinggi risiko semakin tinggi pula return yang akan didapatkan oleh investor, begitupula sebaliknya semakin kecil risiko maka return yang didapatkan pun semakin kecil. Menurut 
Zubir (2013:19) risiko dapat didefinisikan sebagai perbedaan antara hasil yang diharapkan (expected return) dan realisasinya. Makin besar penyimpangannya, makin tinggi pula resikonya. Berdasarkan pengertian return, bahwa return suatu saham adalah hasil yang diperoleh dari investasi dengan cara menghitung selisih darga saham periode berjalan dengan periode sebelumnya, maka dapat ditulis dengan rumus :

$$
R_{i t}=\frac{P_{t}-P_{t-1}}{P_{t-1}}
$$

\section{Beta}

Menurut Jogiyanto (2013) berpendapat bahwa beta adalah pengukuran pengembalian volatilitas pada sekuritas atau portofolio menuju pengembalian pasar. Beta sebagai risiko sistematis alat rasio mempengaruhi pengembalian portofolio, karena masing-masing investasi tergantung pada beta yang mengukur varian pengembalian terkait dengan pengembalian pasar. rumus mencari beta dengan metode indeks tunggal adalah sebagai berikut:

$$
\beta_{i}=\frac{n \sum R_{i} R_{m}-\sum R_{i} \sum R_{m}}{n \sum R_{m}{ }^{2}-\left(\sum R_{m}\right)^{2}}
$$

Dimana :

$$
\begin{array}{ll}
\beta & =\text { Beta } \\
\mathrm{n} & =\text { Periode } / \text { Jumlah Data } \\
\text { Rmt } & =\text { Return Pasar } \\
\text { Rit } & =\text { Return Sekuritas }
\end{array}
$$

\section{Capital Asset Pricing Model (CAPM)}

Dalam memperhitungkan tingkat keuntungan portofolionya, investor membutuhkan alat analisis. Model keseimbangan umum memungkinkan investor untuk mengukur risiko dan return. Salah satunya adalah model Capital Asset Pricing Model (CAPM). Menurut Gitman dan Zutter (2012 : 329) dalam CAPM terdapat dua jenis resiko. Yang pertama adalah resiko tidak sistematis dan yang kedua adalah resiko sistematis. Apabila kedua jenis resiko tersebut digabung, maka hal tersebut dinamakan resiko total. Walaupun Capital Asset Pricing Model belum dapat dibuktikan secara empiris, Model CAPM sudah luas digunakan karena model ini mempunyai akurasi yang cukup baik dalam menentukan return suatu saham.

Hal yang paling utama dari Capital Assets Pricing Model ini adalah pernyataan mengenai hubungan antara expected risk premium dari individual assets dan systematic risk-nya. Jack Treynor, William Sharpe dan John Lintner pada sekitar tahun 1960-an memformulasikan CAPM seperti berikut ini :

$$
E\left(R_{i}\right)=R_{f}+\left(R_{m}-R_{f}\right) \beta_{i}
$$

Formulasi di atas mengatakan bahwa tingkat keuntungan yang diharapkan dari suatu saham $E\left(R_{I}\right)$ sama dengan tingkat risiko $R_{f}$ ditambah dengan premi risiko $\left(R_{m}-R_{f}\right) \beta_{i}$ 
Semakin besar risiko saham $\beta_{i}$ semakin tinggi risiko yang diharapkan dari saham tersebut dan dengan demikian semakin tinggi pula tingkat keuntungan yang diharapkan. Untuk mengestimasi besarnya koefisien beta, digunakan market model dengan persamaan dapat dituliskan sebagai berikut:

$$
R_{i}=\alpha_{i}+\beta_{i} R_{m}+e_{i}
$$

Dimana :

$$
\begin{array}{llll}
\mathrm{Ri} & =\text { return sekuritas } \mathrm{i} & \beta \mathrm{i} & =\text { slope } \\
\mathrm{RM} & =\text { return } \text { indeks pasar } & \text { ei } & =\text { random residual error } \\
\alpha \mathrm{i} & =\text { intersep }=\text { resiko unik perusahan } & &
\end{array}
$$

\section{Indeks Saham Kompas 100}

Indeks kompas 100 merupakan suatu indeks saham dari 100 saham perusahaan publik yang diperdagangkan di Bursa Efek Indonesia (BEI). Indeks kompas 100 secara resmi diterbitkan oleh Bursa Efek Indonesia (BEI) bekerjasama dengan koran kompas pada tanggal 10 Agustus 2007. Adanya indeks kompas 100, diharapkan dapat memberi manfaat bagi para investor, pengelola portofolio dan fund manager sehingga dapat digunakan sebagai acuan dalam menciptakan kreatifitas pengelolaan dana yang berbasis saham. Tujuan utama BEI dalam penerbitan indeks kompas 100 antara lain guna penyebar luasan informasi pasar modal serta menarik minat masyarakat untuk mengambil manfaat dari keberadaan BEI, baik untuk investasi maupun mencari pendanaan bagi perusahaan dalam mengembangkan perekonomian nasional.

\section{METODOLOGI}

Data yang digunakan dalam penelitian ini adalah data sekunder tahunan dari tahun 2013 sampai 2017 berupa return saham perusahaan kompas 100 yang di jadikan sampel, suku bunga dan indeks harga saham gabungan. Populasi yang digunakan dalam penelitian ini adalah seluruh saham yang terdapat pada perusahaan kompas 100 yang terdaftar di Bursa Efek Indonesia. Sedangkan penentuan sampel dalam penelitian ini menggunakan metode purposive sampling. Populasi pada penelitian ini sebanyak 100 perusahaan, dan sebanyak 58 perusahaan yang memenuhi persyaratan dan digunakan pada penelitian saham kompas 100. 
Tabel 1

Operasional Variabel

\begin{tabular}{|c|c|c|c|c|}
\hline No. & Variabel & Definisi & Skala & Pengukuran \\
\hline 1 & $\begin{array}{l}\text { Return Saham } \\
\left(\mathrm{R}_{\mathrm{i}}\right)\end{array}$ & $\begin{array}{l}\text { Return yang telah diterima investor } \\
\text { dari transaksi yang berupa capital } \\
\text { gain. Hasil selisih antara harga } \\
\text { saham i pada periode } \mathrm{t} \text { dikurangi } \\
\text { harga saham i sebelum periode } \mathrm{t} \text { lalu } \\
\text { hasilnya dibagi dengan harga saham } \\
\text { i sebelum periode } \mathrm{t}\end{array}$ & Rasio & $R i t=\frac{P t-P t-1}{P t-1}$ \\
\hline 2. & $\begin{array}{l}\text { Return Pasar } \\
(\mathrm{Rm})\end{array}$ & $\begin{array}{l}\text { Return yang diperoleh dari } \\
\text { perbandingan indeks saham yang } \\
\text { aktif diperdagangkan. Hasil selisih } \\
\text { dari Indeks Harga Saham Gabungan } \\
\text { pada periode t dikurangi Indeks } \\
\text { Harga Saham Gabungan sebelum } \\
\text { periode t dibagi dengan Indeks Harga } \\
\text { Saham Gabungan sebelum periode t }\end{array}$ & Rasio & $\begin{array}{l}R m \\
=\frac{I H S G t-I H S G t-1}{I H S G t-1}\end{array}$ \\
\hline 3. & $\begin{array}{lr}\text { Return } & \text { Aset } \\
\text { Bebas Resiko } \\
\text { (Rf) }\end{array}$ & $\begin{array}{l}\text { Return yang diperoleh dari } \\
\text { perbandingan indeks saham yang } \\
\text { aktif diperdagangkan. Hasil selisih } \\
\text { dari Suku Bunga pada periode t } \\
\text { dikurangi Suku Bunga periode } \\
\text { sebelumnya dibagi dengan Suku } \\
\text { Bunga periode sebelumnya }\end{array}$ & Rasio & $\begin{array}{l}R f \\
=\frac{S B I t-S B I t-1}{S B I t-1}\end{array}$ \\
\hline
\end{tabular}

\section{Uji Hipotesis}

Pengujian hipotesis dalam penelitian ini di tentukan berdasarkan hasil dari uji nonparametrik yaitu Wilcoxon Signed Rank Test. Model uji beda ini digunakan untuk menganalisis model penelitian pre-post atau sebelum dan sesudah. Uji beda digunakan periode pengamatan yang berbeda (Pramana, 2012).

1. Wilcoxon Signed Rank Test

Wilcoxon Signed rank test merupakan uji non-parametrik yang digunakan untuk menganalisis data berpasangan karena adanya dua perlakuan yang berbeda (pramana,2012). Wilcoxon signed rank test digunakan apabila data tidak berdistribusi normal. Dasar pengambilan keputusan untuk menerima atau menolak Ho pada uji wilcoxon signed rank test adalah sebagai berikut:

a. Jika probabilitas (Asymp.Sig) < 0,05 Maka Ho ditolak dan Ha diterima.

b. Jika probabilitas (Asymp.Sig) > 0,05 maka Ho diterima dan Ha ditolak.

Berikut ini adalah prosedur uji wilcoxon signed rank test (Siregar, 2013): 
a. Menentukan Hipotesis

Hipotesis yang ditentukan dalam pengujian wilcoxon signed rank test ini adalah sebagai berikut:

Ho : Tidak terdapat perbedaan yang signifikan antara return saham pada saat sebelum dan sesudah analisis Capital Asset Pricing Model.

$\mathrm{Ha}$ : Terdapat perbedaan yang signifikan antara return saham pada saat sebelum

Dan sesudah analisis Capital Asset Pricing Model.

b. Menentukan level of significant sebesar $5 \%$ atau 0,005

c. Menentukan kriteria pengujian

Ho ditolak jika nilai probabilitas $<0,05$ berarti terdapat perbedaan yang signifikan dalam return saham pada saat sebelum dan sesudah Capital Asset Pricing Model. Ho diterima jika nilai probabilitas $>0,05$ berarti terdapat perbedaan yang tidak signifikan dalam return saham pada saat sebelum dan sesudah Capital Asset Pricing Model.

d. Penarikan kesimpulan berdasarkan pengujian hipotesis.

\section{HASIL DAN PEMBAHASAN}

\section{Deskripsi Statistik}

Sampel dalam penelitian ini adalah 58 dari 100 emiten yang termasuk dalam indeks saham kompas 100. Deskripsi penelitian ini meliputi rata-rata return saham perusahaan sampel dari tahun 2013-2017, rata-rata expected return dari tahun 2013-2017.

\section{Uji Hipotesis}

Tabel 2

Uji Non-Parametrik Wilcoxon

\begin{tabular}{|ll|r|r|r|}
\hline & \multicolumn{1}{|c|}{ N } & Mean Rank & Sum of Ranks \\
\hline \multirow{3}{*}{ er - ar $\quad$ Negative Ranks } & $142^{\mathrm{a}}$ & 154,18 & 21893,50 \\
& Positive Ranks & $148^{\mathrm{b}}$ & 137,17 & 20301,50 \\
& Ties & $0^{\mathrm{c}}$ & & \\
& Total & 290 & & \\
\hline
\end{tabular}
a. Expected Return < Actual Return
b. Expected Return > Actual Return
c. Expected Return $=$ Actual Return

a. Negative rank atau selisih (negatif) anatara hasil actual return dan expected return terdapat 142 data negatif $(\mathrm{N})$ yang artinya terdapat 142 return yang mengalami penurunan dari nilai actual return ke expected return. Mean rank atau rata-rata 
penurunan tersebut adalah sebesar 154,18, sedangkan jumlah rank negatif atau sum of ranks adalah 21893,50.

b. Positive rank atau selisih (positif) anatara hasil analisis capm untuk actual return dan expected return terdapat 148 data positif $(\mathrm{N})$ yang artinya terdapat 148 return yang mengalami peningkatan dari actual return ke expected return. Mean rank atau rata-rata peningkatan tersebut adalah sebesar 137,17, sedangkan jumlah rank positif atau sum of rank adalah sebesar 20301,50.

c. Ties adalah kesamaan nilai actual return dan expected return, disini nilai ties adalah 0 , sehingga dapat dikatakan bahwa tidak ada nilai yang sama antara actual return dengan expeceted return.

Tabel 3

Uji Statistik

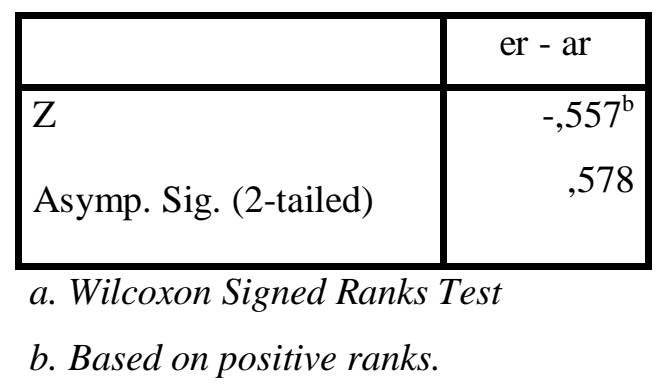

\section{Uji Signifikansi}

Berdasarkan hasil perhitungan uji wilcoxon yang telah diolah, diperoleh Z sebesar -0,557 dengan asimptotik signifikansi untuk uji dua arah sebesar 0,578, karena sig > 0,05 maka Ho diterima. Hasil ini menunjukkan terdapat perbedaan yang tidak signifikan dalam return saham pada saat sebelum dan sesudah Capital Asset Pricing Model.

\section{KESIMPULAN}

Berdasarkan hasil analisis dan pembahasan yng telah dikemukakan, dapat diambil kesimpulan sebagai bahwa secara statistik terdapat hasil akurasi yang signifikan pada Capital Asset Pricing Model (CAPM) dalam memprediksi return saham indeks kompas 100 yang terdaftar di Bursa Efek Indonesia periode 2013-2017.

\section{SARAN}

Setelah melakukan analisis dan pembahasan terhadap masalah yang terjadi, yaitu Capital Asset Pricing Model dalam memprediksi return saham pada indeks kompas 100 yang terdaftar di Bursa Efek Indonesia periode 2013-2017, saran yang dapat penulis berikan yaitu diharapkan para investor dapat memprediksi return dan risiko sebelum melakukan investasi dengan menggunakan metode Capital Asset Pricing Model (CAPM), sehingga dapat melakukan investasi pada saham yang tepat. 


\section{REFERENSI}

Isnurhadi, (2014). Analisis Model CAPM dalam Memprediksi Tingkat Return Saham Syariah dan Konvensional, Jurnal Ilmiah Manajemen dan Bisnis Terapan tahun XI No.1, Universitas Sriwijaya.

Lemiyana, (2015). Analisis Model CAPM dan APT dalam Memprediksi Tingkat Return Saham Syariah, Jurnal I-Finance Vol.1 No. 1, Universitas Islam Negeri Raden Fatah Palembang.

American Economic Review, Vol.59, No.5.

Jogiyanto Hartono, M.B.A., Ak. (2010). Teori Portofolio dan Analisis Investasi, Edisi Ketujuh, Fakultas Ekonomika dan Bisnis UGM Yogyakarta.

Ahmad Kamarudin. (2001). Dasar - dasar Manajemen Investasi dan Portofolio, edisi revisi, cetakan kedua, PT Asdi Mahasatya.

Roll, R. And Ross, S., A. (1984). Critical Reexemanation of the Empirical Evidence on the Arbitrage Pricing Theory, Reply, Journal of Fianace, Vol. XXXV. Juni 1984.

Gencar Candra Premananto, Muhammad Madyan. (2004). Perbandingan Keakuratan Capital Asset Pricing Model dan Arbitrage Pricing Theory dalam Memprediksi Tingkat Pendapatan Saham Industri Manufaktur Sebelum dan Semasa Krisis Ekonomi, Fakultas Ekonomi, Universitas Airlangga Jurnal Penelitian Dinamika Sosial Vol. 5 No. 2 Agustus 2004: 125-139.

Suad Husnan. (2004). Dasar - Dasar Teori Portofolio dan Analisis Sekuritas, Yogyakarta Penerbit UPP AMP YKPN. 